\title{
ON THE TEMPERATURE DISTRIBUTION OF GLACIERS IN CHINA
}

\author{
By HUANG MAOHUAN
}

(Lanzhou Institute of Glaciology and Geocryology, Academia Sinica, Lanzhou 730000, China)

ABSTRACT. To date, the temperatures of 22 glaciers in China have been measured. It is suggested that the minimum temperature at the base of the active layer in the upper part of the ablation area $\left(T_{\min }\right)$ be used as a characteristic temperature and compared with mean annual air temperature $\left(T_{\mathrm{a}}\right)$. The temperature distribution is discussed for various glaciers. Polar-type glaciers are characterized by low temperatures with $T_{\min }<-10^{\circ} \mathrm{C}, T_{\text {min }}$ close to $T_{2}$, and a cold base in general; sub-polar-type glaciers with $-10^{\circ} \mathrm{C}<T_{\min }<-1.0^{\circ} \mathrm{C}, T_{\min }$ higher than $T_{\mathrm{a}}$, and a melting base are usually located beneath the middle of the ablation area; and temperate-type glaciers with $T_{\min }$ $>-1.0^{\circ} \mathrm{C}$, certainly higher than $T_{\mathrm{a}}$, and a sub-freezing near-surface layer in the ablation area all the year round, because the snow cover is thinner in winter.

\section{INTRODUCTION}

China has a large number of mountain glaciers with a total area of $58650 \mathrm{~km}^{2}$. Their temperature is of interest to glaciologists. Since 1959, every major investigation on glaciers has included temperature measurements, and much data has been obtained to date. The temperature measurements on glaciers in China can be divided into three periods depending on the technique of drilling and measuring. They are: (1) 1959-76, by manual drilling, drill depth not more than $10 \mathrm{~m}$; measured by copper resistance thermometers, occasionally by thermistors, with an accuracy of $0.2 \mathrm{~K}$ or so; (2) $1977-85$, a steam drill was employed and on some glaciers a depth of $30 \mathrm{~m}$ was reached; quartz thermometers with an accuracy of $0.05 \mathrm{~K}$ were used; (3) since 1986, by using a hot-water drill and ice-core auger, drill depths have exceeded $100 \mathrm{~m}$, and an integrated circuit sensor with an accuracy of $0.05-0.1 \mathrm{~K}$ has been used. By the end of 1988 , there were 22 glaciers whose temperatures had been measured (Fig. 1; Table I). A summary of the temperature distribution of various glaciers is presented in this paper.

For comparison, the mean annual air temperatures $\left(T_{\mathrm{a}}\right)$ at the equilibrium line are also presented. They are calculated on the basis of measurements at the nearest meteorological stations and on lapse rates determined by short-term measurements. A temperature jump from a nonglacierized area to a glacierized area is taken into account in the calculation. The uncertainty in air temperature is estimated to be about $\pm 1 \mathrm{~K}$.

\section{THE CLASSIFICATION OF GLACIERS IN CHINA}

Lai and Huang $(1989,1990)$ suggested a new principle on which glaciers are classified by means of glaciological indices at the equilibrium line which can be used to classify numerically the glaciers in China. The indices are $T_{\mathrm{a}}$, the mean air temperature in summer, the annual precipitation, $16 \mathrm{~m}$ temperature measured in the upper part of the ablation area, and a parameter of flow velocity. A fuzzy cluster analysis was conducted, then verified by stepwise discriminatory analysis. As a result, 22 glaciers in China were classified into types I, II, III, and IV. In the fuzzy cluster analysis, types II and III are clustered together when $\lambda>0.890$, and then clustered with type I when $\lambda>0.878$, where $\lambda$ is the cluster level. Lai and Huang (1989a) named types I, II, III, and IV polar type, extra-continental type, sub-continental type, and maritime type, respectively. Incorporating comments of some Chinese glaciologists who do not agree that polar glaciers appear in mid-latitudes, Lai and Huang (1990) changed the names of the four types to quasi-polar, sub-polar $\mathrm{A}$, sub-polar $\mathrm{B}$, and temperate. In this paper we name them polar type, sub-polar type, and temperate type, respectively, so as to conform more closely to western terminology (Table II). The classification principle, however, is different from Ahlmann's (1935); we add the word "type" to every term for distinction.

Stepwise discriminatory analysis (Lai and Huang, 1989 1990) indicated that $T_{\mathrm{a}}$, the mean air temperature in summer, and the annual precipitation at the equilibrium line are the dominant variables, but that the ice temperature was not discriminatory. Because of this lack of discrimination by the $16 \mathrm{~m}$ ice temperature, we do not attempt to classify the glaciers on the basis of the glacier-temperature regime, but instead limit the following discussion to the temperature distribution of various glaciers in China.

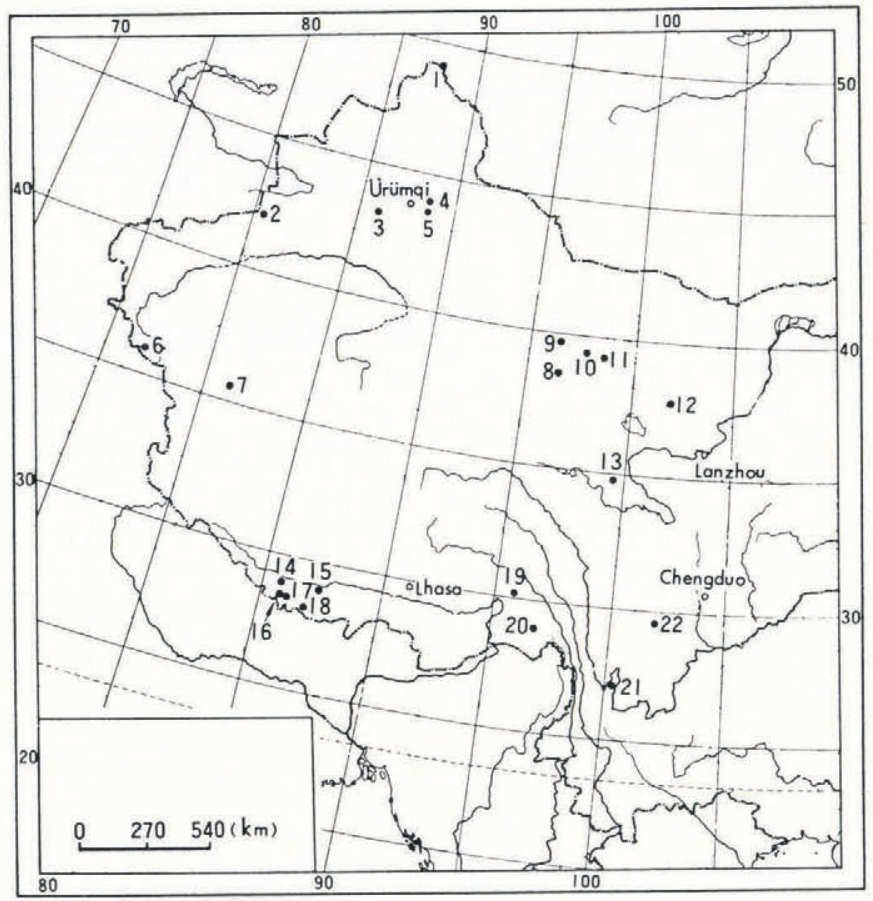

Fig. 1. Index map showing the locations of the glaciers in China whose temperatures have been measured. Glacier names are listed in Table I. 


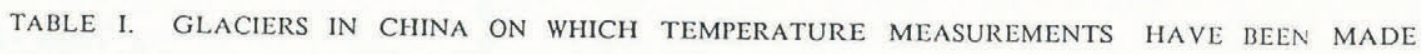

\begin{tabular}{|c|c|c|c|c|c|c|c|c|}
\hline No. & Glacier & Mountains & $\begin{array}{l}\text { Length } \\
\qquad \mathrm{km}\end{array}$ & Pattern & $\begin{array}{c}E L A \\
\mathrm{~m}\end{array}$ & Type & $\begin{array}{l}\text { Measure- } \\
\text { ment year }\end{array}$ & Information source \\
\hline 1 & Hars & Altay & 10.8 & Valley & 3200 & III & 1980 & Wang and others, 1983 \\
\hline 2 & West-Qiongtailan & Tian Shan & 25.2 & Valley & 4500 & III & 1978 & Wang and others, 1985 \\
\hline 3 & No. 1, Urumqi & Tian Shan & 2.2 & Cirque-valley & 4030 & II & 1986 & Cai and others, 1988 \\
\hline 4 & No. 5 , Sigonghe & Tian Shan & 4.4 & Cirque & 3900 & III & 1981 & Ren, 1983 \\
\hline 5 & Heiguo, Bogda & Tian Shan & 7.1 & Valley & 3900 & III & 1985 & Personal communication from Shao W. \\
\hline 6 & Qogir & Karakorum & 21.3 & Valley & 5600 & III & 1986 & Personal communication from Qin D. \\
\hline 7 & Chongce & Kunlun & 5.4 & Ice cap & 6000 & III & 1987 & Shao and Liu, 1990 \\
\hline 8 & Dunde & Qilian & 6.2 & Flat topped & 5200 & 1 & 1987 & Wang, 1990 \\
\hline 9 & No. 12, Laohugou & Qilian & 10.0 & Valley & 4700 & I & 1976 & $*$ \\
\hline 10 & Qiyi & Qilian & 3.5 & Cirque-valley & 4650 & I & 1975 & $*$ \\
\hline 11 & No. 5, Yanglonghe & Qilian & 2.6 & Valley & 4600 & II & 1977 & Huang and others, 1982a \\
\hline 12 & No. 4, Shuiguanhe & Qilian & 2.1 & Cirque & 4460 & II & 1963 & Personal communication from Cao $\mathrm{M}$. \\
\hline 13 & Halong & A'nyemagên & 8.0 & Valley & 4950 & III & 1981 & Wang, 1987 \\
\hline 14 & No. 71 , Poiqu & Himalaya & 4.0 & Valley & 5640 & III & 1987 & Liu and Sharmal, 1988 \\
\hline 15 & No. 18, Natangqu & Himalaya & 3.8 & Valley & 5530 & III & 1987 & Liu and Sharmal, 1988 \\
\hline 16 & Yebokangjiale & Himalaya & 12.5 & Valley & 6000 & III & 1964 & Huang, 1982 \\
\hline 17 & No. 7, Nakeduola & Himalaya & 3.5 & Flat topped & 6000 & III & 1964 & Huang, 1982 \\
\hline 18 & Rongbuk & Himalaya & 22.2 & Valley & 5800 & III & 1966 & $\mathrm{Xie}$ and Wang, 1975 \\
\hline 19 & No. 3, Guxiang & Nyainqêntanglha & 1.7 & Cirque & 4800 & IV & 1965 & Yuan and others, 1982 \\
\hline 20 & Azha & Gangrigabu & 20.0 & Valley & 4600 & IV & 1973 & $\mathrm{Li}, 1975$ \\
\hline 21 & No. 1, Baishuihe & Hengduan & 2.5 & Cirque-valley & 4700 & IV & 1982 & Personal communication from Wang $L$. \\
\hline 22 & Dagongba & Hengduan & 11.0 & Valley & 5100 & IV & 1983 & Personal communication from Wang $\mathrm{L}$. \\
\hline
\end{tabular}

Glacier type is given in section 2 and Table II.

* Provided by Investigation Team on Utilization of Ice and Snow in the Qilian Shan, Lanzhou Institute Glaciology and Cryopedology, of Academia Sinica.

TABLE II. COMPARISON BETWEEN THE CHANGED CLASSIFICATION TERMS

$\begin{array}{lccl}\begin{array}{l}\text { Numerical type } \\ \text { Lai and Huang (1989) }\end{array} & I & I I \quad I I & I V \\ \text { Lai and Huang (1990) } & \text { Quasi-polar } & \underbrace{\text { Extra-continental Sub-continental }}_{\text {Continental }} & \text { Maritime } \\ \text { This paper } & \text { Polar } & \text { Sub-polar A Sub-polar B } & \text { Temperate } \\ \text { Sub-polar } & \text { Temperate }\end{array}$

\section{POLAR-TYPE GLACIERS}

Glaciers Nos $7-9$ in Figure 1 and Table I are classified as polar type. Their $T_{\mathrm{a}}$, annual precipitation, and mean air temperature in summer at the equilibrium line are below $-12^{\circ} \mathrm{C}, 450 \mathrm{~mm}$, and $-1{ }^{\circ} \mathrm{C}$, respectively. The ice temperature is quite low and the basal temperatures are generally below the melting point.

\subsection{Chongce Ice Cap (No. 7)}

Chongce Ice Cap, $18.1 \mathrm{~km}^{2}$ in area, was investigated by the Sino-Japanese Joint Expedition to the West Kunlun Mountains in 1987. $T_{\text {a }}$ at the equilibrium line $(6000 \mathrm{~m})$ is estimated to be $-13.4^{\circ} \mathrm{C}$, whereas the $16 \mathrm{~m}$ temperature was $-13.2{ }^{\circ} \mathrm{C}$ (Shao and Liu, 1990). Based on a model, Zhou and Han (1990) were able to draw a graph of the twodimensional temperature distribution as shown in Figure 2. The ice temperature is quite low and the base is entirely frozen. In Zhou and Han's (1990) model, the four measured temperature profiles shown in Figure 2 were used; in addition, heat conduction, advection and geothermal flux in the vertical direction, and internal heating were taken into account, on the asusmption that the glacier is in steady state.

\subsection{Dunde Glacier (No. 8)}

In 1987, a Sino-U.S. Joint Expedition bored holes at the summit of Dunde Glacier $(5324 \mathrm{~m})$, a flat-topped glacier in the Qilian Mountains with an area of $57 \mathrm{~km}^{2}$. In one of the holes, $135 \mathrm{~m}$ deep, which reached the bed, a basal temperature of $-4.8^{\circ} \mathrm{C}$ was measured (Wang, 1990). $T_{2}$ at the equilibrium line $(5200 \mathrm{~m})$ is estimated to be $-12.8^{\circ} \mathrm{C}$.

\subsection{Glacier No. 12, Laohuguo (No. 9)}

Glacier No. 12, Laohuguo, Qilian Mountains, is a valley glacier, $10 \mathrm{~km}$ in length, on which temperature measurements have been made on many occasions. Its temperature is the lowest of those valley glaciers measured to date in China. In the upper part of the ablation area $(4650 \mathrm{~m}, 50 \mathrm{~m}$ below the equilibrium line), and ice temperature of $-12.8^{\circ} \mathrm{C}$ was recorded at a depth of $7 \mathrm{~m}$ on 31 July 1976, leading to an estimate for the $16 \mathrm{~m}$ temperature of $-10.5^{\circ} \mathrm{C}$ (see section 4.5). In the middle of the ablation area, the base may locally reach the melting point. This is based on the observation that during 1960-61 the ratio of summer velocity to winter velocity was close to 1.6 near the middle of the ablation area (Huang and Sun, 1982).

\section{SUB-POLAR-TYPE GLACIERS}

Physically, there is no difference between type II and type III glaciers in Table II. Chinese glaciologists have, in the past, usually regarded type II as extra-continental type and type III as sub-continental type, cf. Shi and others (1988). In this paper we combine both into one type sub-polar type. 


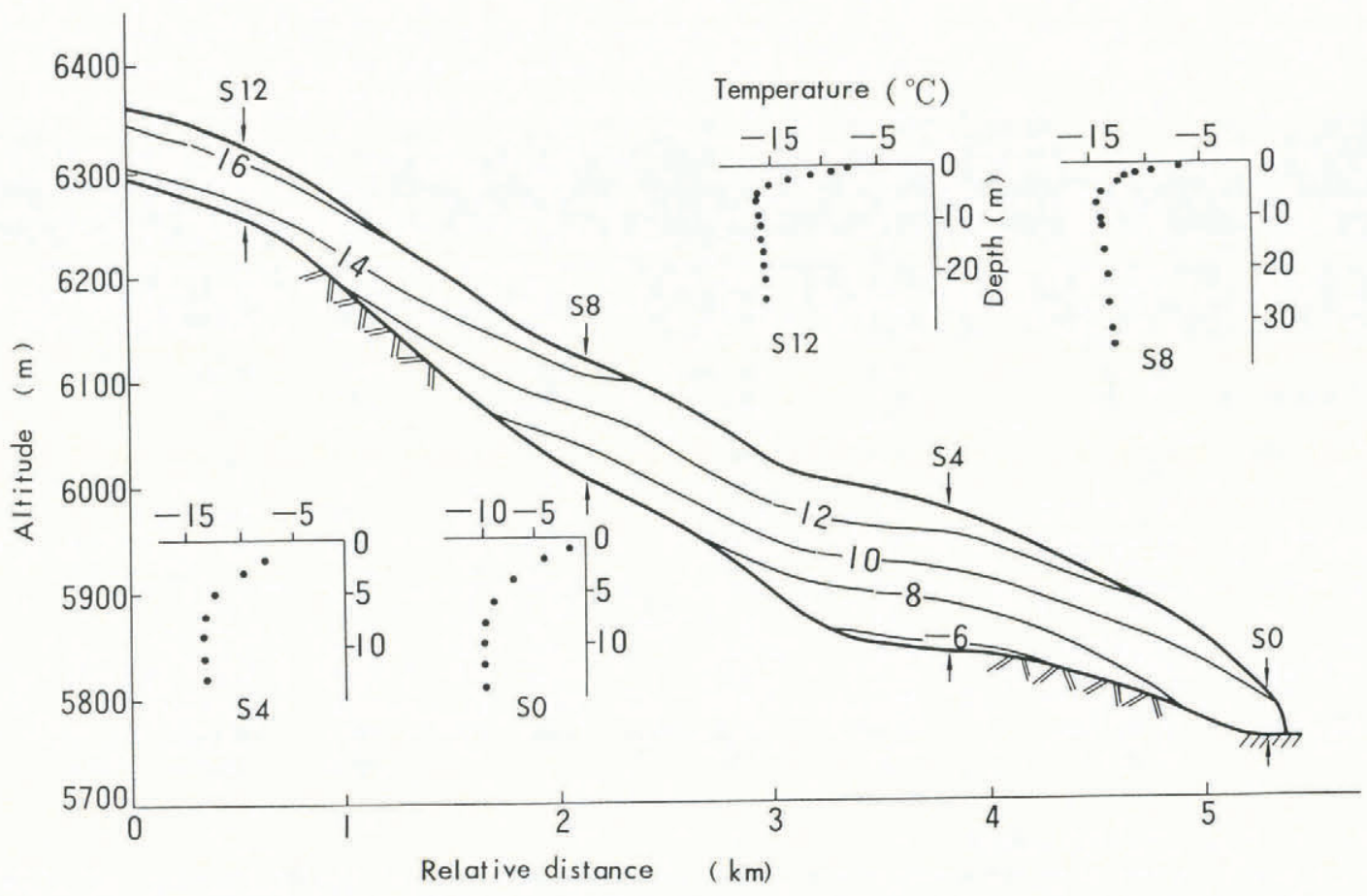

Fig. 2. Two-dimensional temperature distribution in a longitudinal profile of Chongce Ice Cap. West Kunlun Mountains (after Zhou and Han, 1990).

4.1. Temperature profile in the active layer near the equilibrium line

Modifying the solution of the equation for heat conduction in a semi-infinite medium subject to an harmonic change in surface temperature, a semi-empirical formula

$$
T(y, t)=T_{\mathrm{S}} \exp \left[-y(\omega / 2 k)^{\frac{1}{2}}\right] \sin \left[\omega t-y(\omega / 2 k)^{\frac{1}{2}}\right]+T_{0}(y)
$$

can be derived to describe the temperature profile in nearsurface layers at or near the equilibrium line and where the surface elevation is changing only slowly (Huang and others, 1982b). In Equation (1) $T_{\mathrm{S}}$ is an apparent amplitude of surface-temperature change, $t$ is the time, $y$ is the distance below the surface, $k$ is thermal diffusivity, and $\omega / 2 \pi$ is the frequency of the surface-temperature change. We are interested in the change with a period of 1 year, i.e. $\omega / 2 \pi=1 \mathrm{a}^{-1}$. The equilibrium temperature $T_{0}(y)$ is found to change with depth and can be fitted to an empirical formula

$$
T_{0}(y)=a_{1}+a_{2} \ln \left(y / y_{0}\right)
$$

where $y_{0}$ is a unit of depth $(1 \mathrm{~m})$, and $a_{1}$ and $a_{2}$ are constants determined by regression analysis of observations, which vary from place to place. $a_{1}=T_{0}(y)$ when $y=1 \mathrm{~m}$, i.e. $a_{1}$ is the equilibrium temperature at a depth of $1 \mathrm{~m}$. Usually $1.2>a_{2}>0$.

When temperature measurements are made at relatively shallow depths, say more than $5 \mathrm{~m}$ and less than $15 \mathrm{~m}$, Equations (1) and (2) can be used to calculate the temperature at the base of the active layer at or near the equilibrium line as long as the measurements were taken at more than two different depths. For calculations, the values of $T_{\mathrm{s}}, a_{1}$, and $a_{2}$ should be determined empirically. The active layer is defined as the uppermost layer of ice in which the amplitude of the annual temperature oscillation is more than $0.2 \mathrm{~K}$. The thickness of the active layer is about $15-20 \mathrm{~m}$.

\subsection{Temperature regime in the infiltration zone}

Considerable surface melting occurs in the infiltration zone of sub-polar-type glaciers during the summer. When melt water refreezes in the snow, latent heat is released, which warms the snow beneath. Percolation and refreezing become major processes of heat transfer in summer, and dominate the temperature profile of the near-surface layer in the infiltration zone all year-round. Cai and others (1986) have suggested mathematical models for calculating the water-heat transfer and the temperature profiles in this zone based on experiments and observations made on Urumqi Glacier No. 1. According to their calculations, the warming effect of melt water may reach a depth of $20 \mathrm{~m}$ by the end of the melt season. Measurements made in the infiltration zone of the eastern tributary of Urumqi Glacier No. 1 showed that it was $0{ }^{\circ} \mathrm{C}$ in the uppermost $11 \mathrm{~m}$ and $\geqslant-0.1^{\circ} \mathrm{C}$ down to a depth of $30 \mathrm{~m}$ during 20 July-10 August 1982 (Zhang and others, 1984). Hooke and others (1983) found a similar penetration depth for this warming.

\subsection{Longitudinal temperature profile}

To describe quantitatively the changing temperature with elevation, Huang and others $(1982 \mathrm{a}, \mathrm{b})$ have suggested that the temperature at the base of the active layer should be used. They have developed a scheme which describes its variation with elevation. Their model has been verified by measurements on Urumqi Glacier No. 1 (Fig. 3). As shown in Figure 3 , the temperature at the base of the active layer decreases with increasing elevation, as does the air temperature, but in the infiltration zone there is a maximum due to the greater warming effect of refreezing melt water. The temperature at the base of the active layer decreases from this maximum both up-glacier and downglacier. However, down-glacier a minimum value does not appear at the equilibrium line, as the model of Huang and others $(1982 \mathrm{a}, \mathrm{b})$ suggests, but somewhere in the upper part of the ablation area. Because the warm ice in the infiltration zone is flowing down-glacier, it takes several years for it to be cooled. This was confirmed by measurements in deep holes in Urumqi Glacier No. 1 in 1986. Figure 4 shows the location of the holes and Figure 5 shows the temperature profiles. The profiles show that the temperature in the upper part of the ablation area $\left(T_{2}\right)$ is lower than that near the equilibrium line $\left(T_{3}\right)$ from the surface to a depth of $88 \mathrm{~m}$ (Cai and others, 1988).

The temperature at the base of the active layer of a sub-polar glacier may reach the melting point if the glacier extends to a sufficiently low elevation (Huang and others, 1982a, b; Hooke and others, 1983).

Measurements made on sub-polar glaciers show that the temperature at the base of the active layer is higher than $T_{\mathrm{a}}$ at the same elevation. 


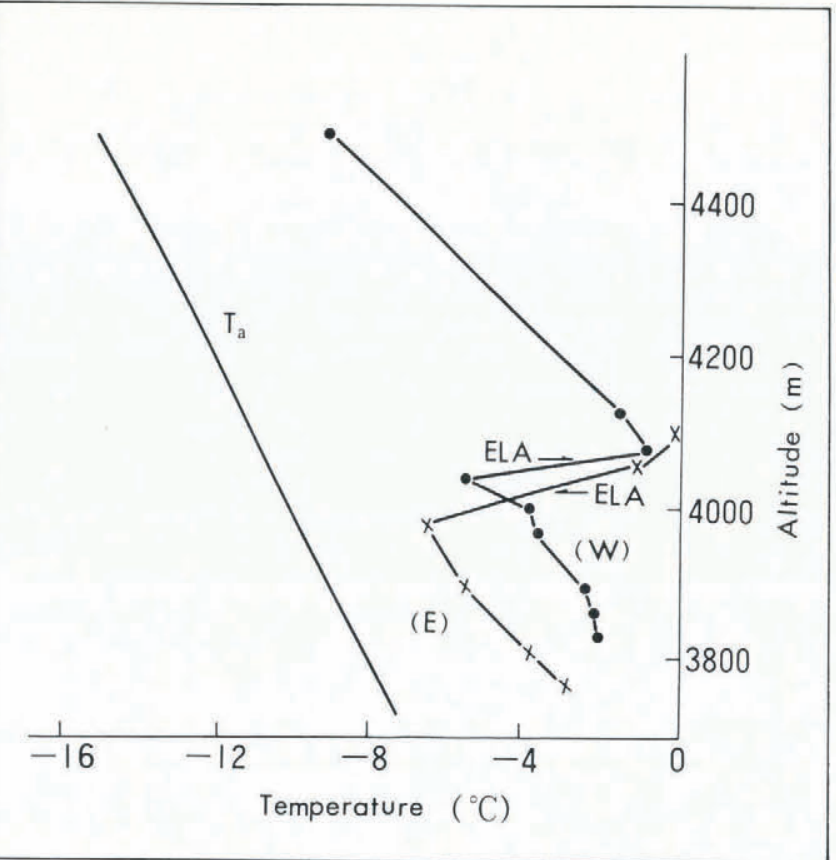

Fig. 3. Two measured temperature profiles showing how the temperature at the base of the active layer changes with altitude on Urumqi Glacier No. 1. E, east tributary; $W$, west tributary; ELA, equilibrium-line altitude; $T_{a}$, air temperature; at the summit it was measured at the base, $8.5 \mathrm{~m}$ deep, others at $16 \mathrm{~m}$ depth (by courtesy of Ren Jiawen).

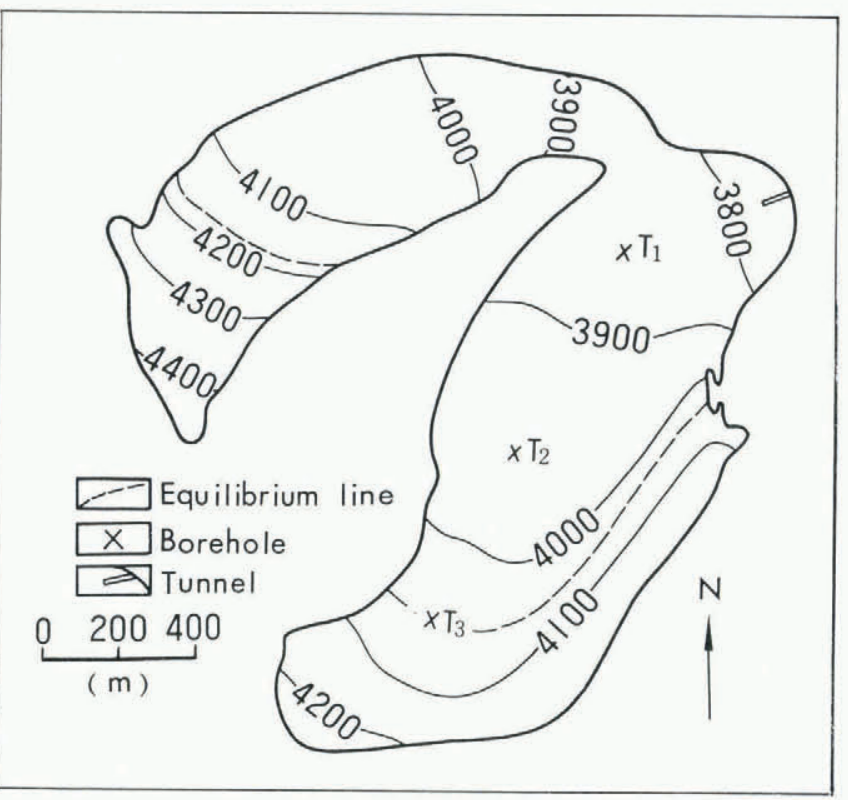

Fig. 4. A map showing the locations of holes for temperature measurement and the artificial tunnel in Urumqi Glacier No. 1.

\subsection{Basal temperature}

Among the sub-polar-type glaciers in China, the basal temperature has been measured only on Urumqi Glacier No. 1. It is estimated by radar sounding that the ice thicknesses at $T_{1}, T_{2}$, and $T_{3}$ (Figs 4 and 5 ) are 96, 138, and $106 \mathrm{~m}$, respectively. Thus, the holes at $T_{3}$ reached and $T_{1}$ is close to the base of the glacier. Integrated-circuit sensors with an accuracy of $\pm 0.05 \mathrm{~K}$ were used to measure the ice temperatures.

A temperature-distribution model based on the measurements in deep holes over a period of several months was made by Cai (unpublished). In the model, glacier flow and heat conduction in horizontal and vertical directions, and the geothermal flux are taken into consideration

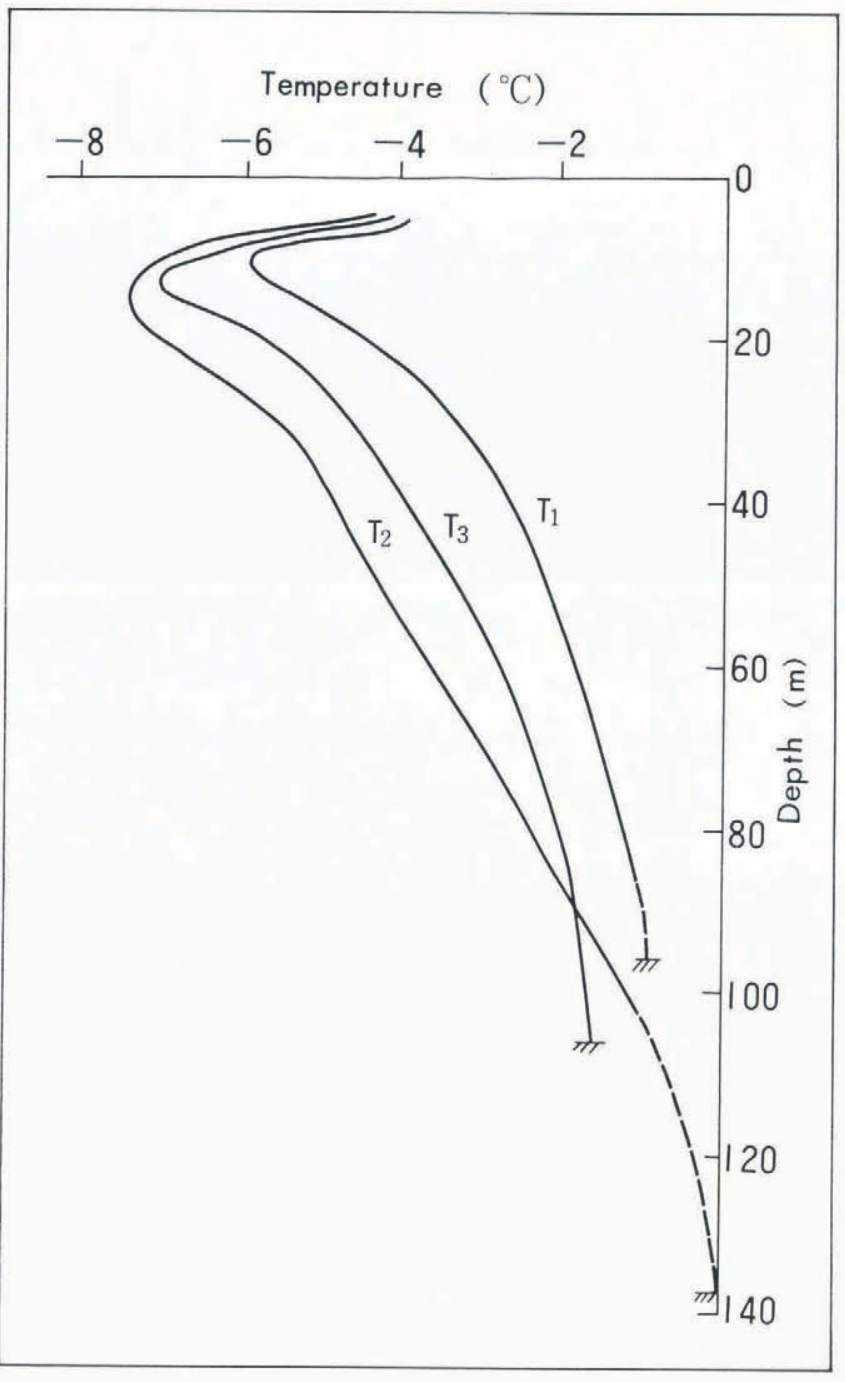

Fig. 5. Temperature profiles measured on Urumqi Glacier No. 1 on 27 September 1986. The dotted lines are extrapolated (after Cai, unpublished).

assuming that the temperature field is stable. As a result, it is found that the highest basal temperature, greater than $-0.5^{\circ} \mathrm{C}$, occurs in the middle of the ablation area, the thickest part of the glacier. We therefore believe that in sub-polar-type glaciers, as long as they are as large or larger than Urumqi Glacier No. 1, a small cirque-valley glacier, the base may be at the melting point at some locations.

In the terminus of Urumqi Glacier No. 1, a new tunnel (Fig. 4) was excavated in the autumn of 1988. The ice temperature was measured while the tunnel was being extended. The temperature profile is shown in Figure 6 . Because the temperatures in the tunnel are below $0{ }^{\circ} \mathrm{C}$ and, in view of the fact that permafrost is present in front of the glacier, the $0^{\circ} \mathrm{C}$ isotherm must lie at a depth of at least a few meters in the bed, as suggested by Echelmeyer and Wang (1987).

\subsection{Regional features}

Huang and others $(1982 \mathrm{a}, \mathrm{b})$ have attempted to describe how the near-surface temperature changes with elevation using measured and calculated temperature at the base of the active layer as a temperature index of the active layer, and using the temperature at the base of the active layer at the equilibrium line as a characteristic temperature to determine the regional features of glacier temperature. As mentioned above, however, the temperature at the equilibrium line does not display significant characteristics. We prefer to take the minimum temperature at the base of the active layer in the upper part of the ablation area $\left(T_{\min }\right)$ as the characteristic temperature for a glacier. However, it is difficult to determine $T_{\min }$ owing to the 


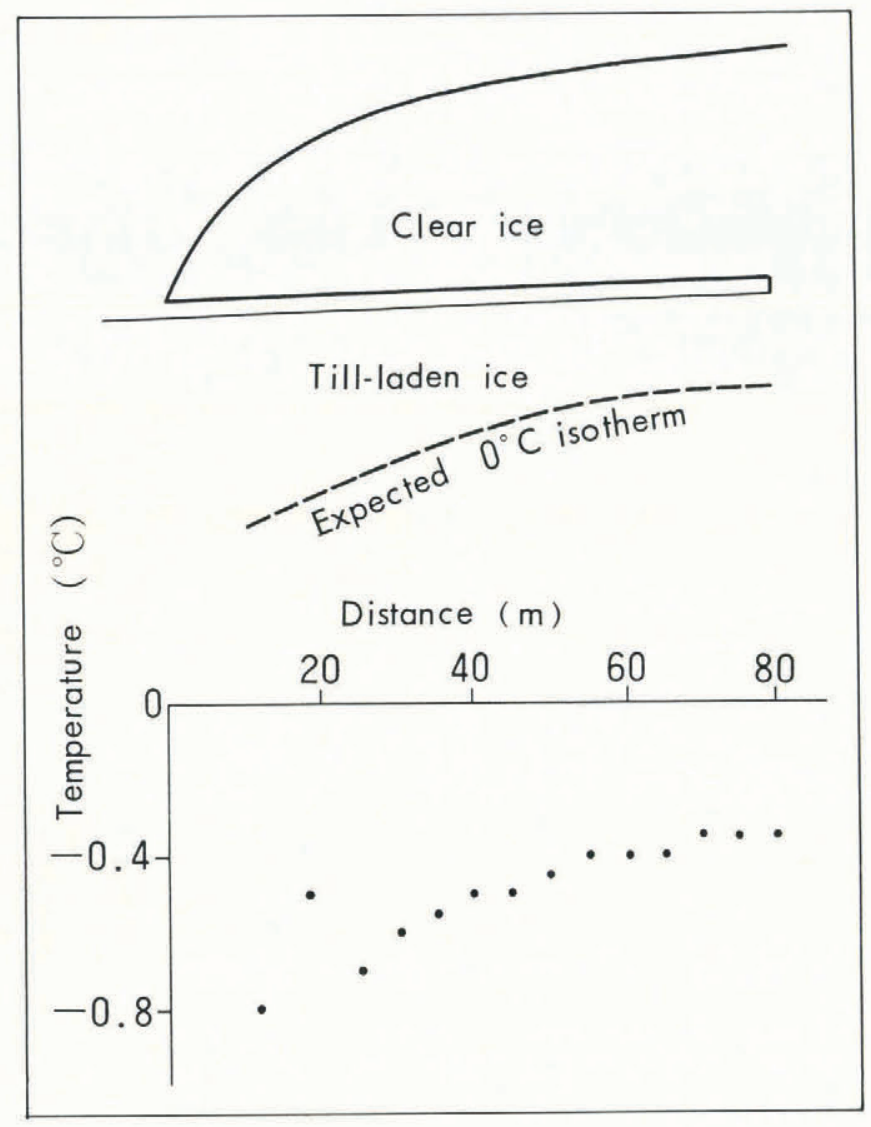

Fig. 6. Section through the tunnel in Urumqi Glacier No. 1 with its temperature profile measured during excavation in September-October 1988 (by courtesy of Zhou Tao).

spatial limitations of the measurements. Therefore, instead of $T_{\min }$, we take a temperature at the base of the active layer measured near the equilibrium line or in the upper part of the ablation area, designated $T_{\min }^{\prime}$.

There are 14 sub-polar-type glaciers in China for which $T_{\min }^{\prime}$ is known. These are listed in Table III together with the altitudes at which the measurements were made. The equilibrium-line altitudes and measurement years of the glaciers in Table III are shown in Table I. In Table III we take the $16 \mathrm{~m}$ temperature as the temperature at the base of the active layer. Equations (1) and (2) are used to calculate $T_{\min }^{\prime}$ if the measured depth is less than $16 \mathrm{~m}$. At Glacier No. 4, Shuiguanhe (No. 12), no measurement was made in the ablation area and therefore $T_{\min }^{\prime}$ is not known for the glacier. The $T_{\min }^{\prime}$ for Glacier Rongbuk (No. 18) in Table III is higher than it should be, as the measurement point was in the lower part of the ablation area. For comparison, estimated $T_{\mathrm{a}}$ at the measurement altitudes are also shown in Table III.

Hooke and others (1983) analysed the complex process controlling the near-surface temperature in the lower part of the accumulation area and in the ablation area on polar and sub-polar glaciers, compared the ice temperature with $T_{\mathrm{a}}$, and pointed out that the principal controlling factors are snow-cover thickness, mean July temperature, and $T_{\text {a }}$

From Table III we can see that $T_{\min }^{\prime}$ is, without exception, a few degrees higher than $T_{\mathrm{a}}$. $T_{\min }^{\prime}$ for a flat-topped glacier, Glacier No. 7, Nakeduola (No. 17), is clearly lower than that for Yebokangjiale Glacier (No. 16), an adjacent valley glacier on the northern slope of Mount Xixiabangma. This is due to the thin snow cover on a flat-topped glacier, which reduces its winter insulating effect. Kotlyakov and Krenke (1982) have mentioned that the accumulation on a flat-topped glacier may be less, at the most $30 \%$, than the average annual precipitation at a fixed geographic position, but on a cirque glacier it is always more than the annual precipitation. The same reasoning could explain why $T_{\min }^{\prime}$ is close to $T_{\mathrm{a}}$ for Chongce Ice Cap (No. 7).

\section{TEMPERATE-TYPE GLACIERS}

Temperature-distribution studies on temperate-type glaciers are not as detailed as on sub-polar-type glaciers in China. Nos $19-22$ in Figure 1 and Table $I$ are temperatetype glaciers, which develop under conditions of the South Asian monsoon circulation. The precipitation on temperatetype glaciers in China is large in summer and low in winter. Therefore, the winter snow cover is not as thick as on other temperate glaciers, thus providing less insulation.

\subsection{Accumulation area}

In the accumulation area of temperate-type glaciers, there is no doubt that the main body of the glacier is at the melting point. The near-surface layer cools during the winter but quickly warms in summer due to melt-water percolation. A measurement made by Wang Lilun from 30 June to 11 July 1982 indicated that in the lower part of the accumulation area of Glacier No. 1, Baishuihe, a $10 \mathrm{~m}$ thick near-surface layer consists of firn, which is at the melting point throughout. If the maximum elevation of a temperate-type glacier were higher than the upper limit of the warm-infiltration zone (wet-snow zone), it would have a temperature distribution similar to that of the cold-infiltra-

TABLE III. $16 \mathrm{~m}$ TEMPERATURE MEASURED AT THE EQUILIBRIUM LINE OR IN THE UPPER PART OF THE ABLATION AREA $\left(T_{\text {min }}^{\prime}\right)$ OF SUB-POLAR-TYPE GLACIERS IN CHINA, COMPARED WITH MEAN ANNUAL AIR TEMPERATURE $\left(T_{\mathrm{a}}\right)$

$\begin{array}{llrrrrr}\text { No. } & \text { Glacier } & \text { Type } & \text { Altitude } & T_{\min }^{\prime} & T_{\mathrm{a}} & T_{\min }^{\prime}-T_{\mathrm{a}} \\ & & & \mathrm{m} & 0^{\circ} \mathrm{C} & 0^{\circ} \mathrm{C} & \mathrm{K} \\ & & & & & & \\ 1 & \text { Hars } & \text { III } & 3180 & -3.5^{*} & -7.3 & 3.8 \\ 2 & \text { West-Qiongtailan } & \text { III } & 4300 & -3.0 & -9.2 & 6.2 \\ 3 & \text { No. 1, Urumqi } & \text { II } & 4033 & -7.3 & -9.9 & 2.6 \\ 4 & \text { No. 4, Sigonghe } & \text { III } & 3750 & -1.4^{*} & -7.2 & 5.8 \\ 5 & \text { Heiguo, Bogda } & \text { III } & 3840 & -3.6 & -8.7 & 5.1 \\ 6 & \text { Qogir } & \text { III } & 5300 & -4.8^{*} & -7.8 & 3.0 \\ 10 & \text { Qiyi } & \text { II } & 4600 & -9.0^{*} & -10.5 & 1.5 \\ 11 & \text { No. 5, Yanglonghe } & \text { II } & 4648 & -7.9 & -11.8 & 3.9 \\ 13 & \text { Halong } & \text { III } & 4900 & -6.6^{*} & -8.3 & 1.7 \\ 14 & \text { No. 71, Poiqu } & \text { III } & 5440 & -3.0^{*} & -6.7 & 3.7 \\ 15 & \text { No. 18, Natangqu } & \text { III } & 5330 & -2.9^{*} & -6.1 & 3.2 \\ 16 & \text { Yebokangjiale } & \text { III } & 5834 & -5.8^{*} & -9.2 & 3.4 \\ 17 & \text { No. 7, Nakeduola } & \text { III } & 5900 & -8.3^{*} & -9.6 & 1.3 \\ 18 & \text { Rongbuk } & \text { III } & 5400 & -1.7^{*} & -6.5 & 4.8\end{array}$


tion zone (percolation zone) of sub-polar-type glaciers. But, in the region of the temperate-type glaciers in the southeastern Qinghai-Xizang (Tibet) Plateau of China, the maximum elevation of the glaciers is usually below $6000 \mathrm{~m}$ a.s.1., which is still in the warm-infiltration zone.

\subsection{Ablation area}

In the near-surface layer, $10 \mathrm{~m}$ or more thick, the temperature of temperate-type glaciers is below but close to $0^{\circ} \mathrm{C}$. Because of the thinner snow cover, the winter cold is able to penetrate deeper. But conductive warming in summer is inhibited by the fact that the ice temperature cannot exceed $0^{\circ} \mathrm{C}$. Most of the heat received at the surface is used in melting. Therefore, summer warming cannot counteract winter cooling. Thus, it is one of the features in the ablation areas of temperate-type glaciers in China that temperate ice is of ten covered by a sub-freezing surface layer. Figure 7 shows two temperature profiles from the ablation areas of temperate-type glaciers in China, both of which have this cold surface layer.

For temperate-type glaciers in China, $T_{\min }$ is $2.6-4.5 \mathrm{~K}$ higher than $T_{\mathrm{a}}$ (Lai and Huang, 1989, 1990).

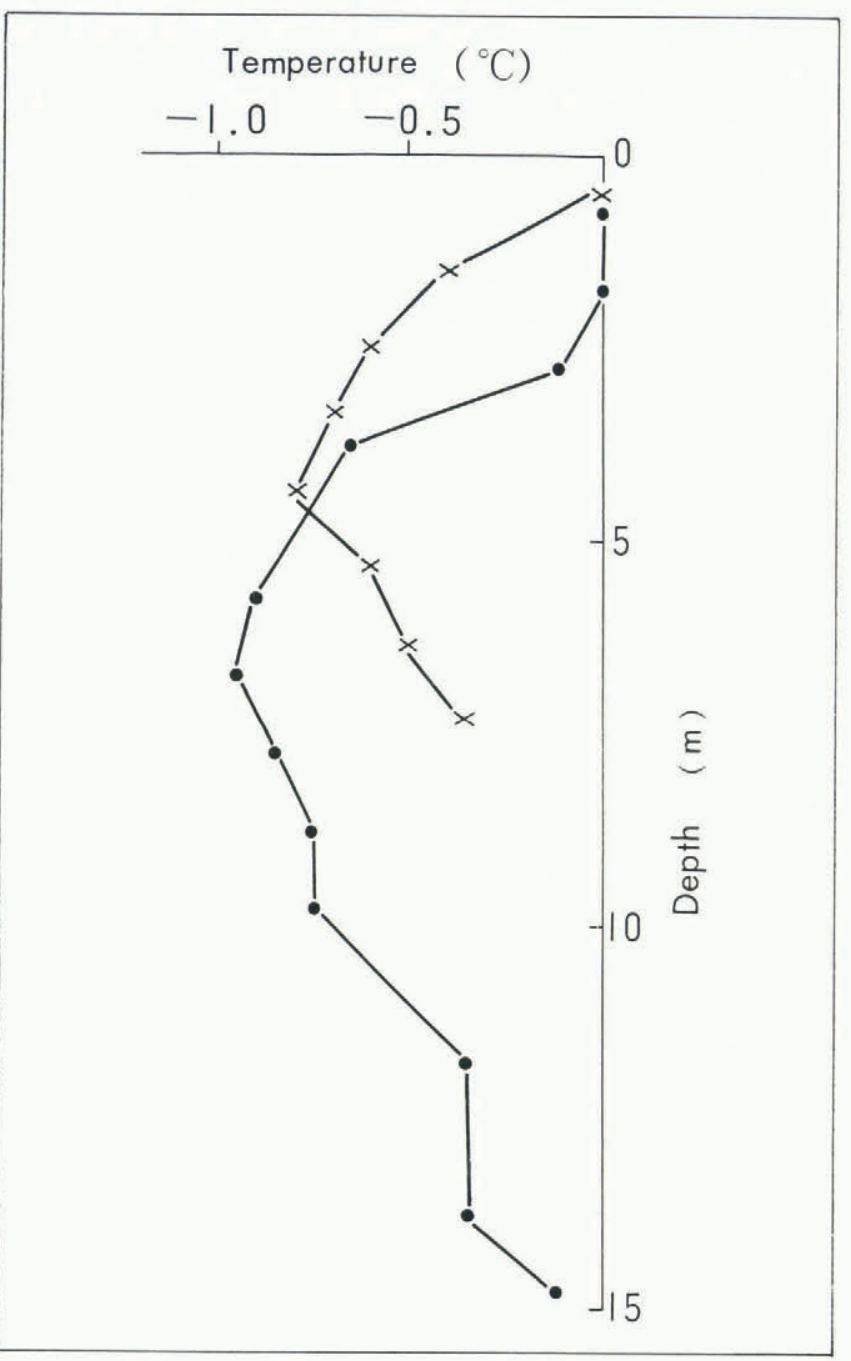

Fig. 7. Temperature profiles of two temperate-type glaciers. $\times$, upper part of the ablation area $(4600 \mathrm{~m})$ on Glacier No. 1, Baishuihe, 11 July 1982; -, middle part of the ablation area $(4540 \mathrm{~m})$ on Dagongba Glacier, 30 September 1982. The glacier surface at the time of measurement is taken as the origin of the depth coordinate (by courtesy of Wang Lilun).

\section{CONCLUSIONS}

The minimum temperature at the base of the active layer in the upper part of the ablation area $\left(T_{\min }\right)$ can be taken as a characteristic temperature of a glacier.

The classification suggested by Lai and Huang (1989, 1990) can be regarded as a basis for discussing the temperature distribution of glaciers in China. In this classification, which is different from Ahlmann's (1935), glaciers are numerically classified by multi-factors which are measured at a fixed place - the equilibrium line. Features of the temperature distribution of glaciers in China can be summarized as follows:

1. Polar-type glaciers - low surface-layer temperature, $T_{\text {min }}<-10^{\circ} \mathrm{C}$, generally with a cold base except for large valley glaciers, where part of the base in the ablation area may be at the melting point. $T_{\min }$ approximates or even equals $T_{\mathrm{a}}$.

2. Sub-polar-type glaciers $--10^{\circ} \mathrm{C}<T_{\min }<-1.0^{\circ} \mathrm{C}$, usually with basal melting in the middle of ${ }_{\text {the }}$ ablation area. The area of basal melting will extend to the terminus in a large valley glacier whose terminus reaches a temperate region. $T_{\min }$ is generally higher than $T_{\mathrm{a}}$.

3. Temperate-type glaciers - the main body, including the base, is at the melting point. However, in the ablation area, the near-surface layer is below $0^{\circ} \mathrm{C}$ all the year round because of a thinner winter snow cover. $T_{\min }$ is certainly higher than $T_{\mathrm{a}}$.

\section{ACKNOWLEDGEMENTS}

The author wishes to express his thanks to Wang Lilun, Ren Jiawen, and Zhou Tao for their courtesy in providing the data and graphs, to W.S.B. Paterson for his encouragement and discussion in the writing of the manuscript, and to R.LeB. Hooke and K. Echelmeyer for assisting with the revision.

\section{REFERENCES}

Ahlmann, H.W. 1935. Contribution to the physics of glaciers. Geogr. J., 86(2), 97-113.

Cai Baolin. Unpublished. The research on the temperature in deep boreholes and temperature distribution modelling in Glacier No. 1, Urumqi River headwaters. (Ph.D. thesis, Academia Sinica. Lanzhou Institute of Glaciology and Geocryology, 1989.) [In Chinese with English abstract.]

Cai Baolin, Xie Zhichu, and Huang Maohuan. 1986. Mathematical models of temperature and water-heat transfer in the percolation zone of a glacier. Cold Reg. Sci. Technol., 12(3), 39-49.

Cai Baolin, Huang Maohuan, and Xie Zhichu. 1988. A preliminary research on the temperature in deep boreholes of Glacier No. 1, Urumqi headwaters. Kexue Tongbao, 33(24), 2054-2056.

Echelmeyer, K. and Wang Zhongxiang. 1987. Direct observation of basal sliding and deformation of basal drift at sub-freezing temperatures. J. Glaciol., 33(113), 83-98.

Hooke, R. LeB., J.E. Gould, and J. Brzozowski. 1983. Near-surface temperatures near and below the equilibrium line on polar and subpolar glaciers. Z. Gletscherkd. Glazialgeol., 19(1), 1-25.

Huang Maohuan. 1982. The temperature regime of the glaciers in north slope of Mt Xixiabangma. In Scientific Expedition Group of Mountaineering Team to Mt Xixiabangma, China, ed. Reports of Scientific Expedition to the Region of Mt Xixiabangma. Beijing, Science Press, 60-66. [In Chinese.]

Huang Maohuan and Sun Zuozhe. 1982. Some flow characteristics of continental-type glaciers in China. $J$. Glaciol. Cryopedol., 4(2), 35-45. [In Chinese with English abstract.]

Huang Maohuan, Wang Zhongxian, and Ren Jiawen. 1982a. Ice temperature of glaciers in China. J. Glaciol. Cryopedol., 4(1), 20-28. [In Chinese with English abstract.]

Huang Maohuan, Wang Zhongxiang, and Ren Jiawen 1982b. On the temperature regime of continental type glaciers in China. J. Glaciol., 28(98), 117-128.

Kotlyakov, V.M. and A.N. Krenke. 1982. Investigations of the hydrological conditions of alpine regions by glaciological methods. International Association of Hydrological Sciences Publication 138 (Symposium at Exeter 1982 - Hydrological Aspects of Alpine and High-Mountain Areas), 31-42. 
Lai Zuming and Huang Maohuan. 1989. A numerical classification of glaciers in China by means of glaciological indices at the equilibrium line. International Association of Hydrological Sciences Publication 183 (Symposium at Baltimore 1989 - Snow Cover and Glacier Variations), 103-111.

Lai Zuming and Huang Maohuan. 1990. A numerical classification of glaciers in China. Proceedings of the Fourth China's National Conference on Glaciology and Geocryology, 19-24. [In Chinese with English abstract.]

Li Jijun. 1975. Recent study on the glaciers in southeastern Tibet. Journal of Lanzhou University (Natural Science edition), 2, 116. [In Chinese.]

Liu Chaohai and C.K. Sharmal, ed. 1988. Report on First Expedition to Glaciers and Glacier Lakes in the Pumqu (Arun) and Poiqu (Bhote-Sun Kosi) River Basins, Xizang (Tibet), China. Beijing, Science Press.

Ren Jiawen. 1983. The ice temperature of Bogda fan-shaped diffluence glacier in Bogda area, Tian Shan. J. Glaciol. Cryopedol., 5(3), 83-89. [In Chinese with English abstract.]

Shao Wenzhang and Liu Zongxiang. 1990. Preliminary studies on the temperature in the surface layer of Guozha glacier and Chongce ice cap in the west Kunlun mts, China. Bull. Glacier Res., 8.

Shi Yafeng, Huang Maohuan, and Ren Binghui, eds. 1988. An introduction to the glaciers in China. Beijing, Science Press. [In Chinese.]

Wang Lilun. 1990. A study of temperature regime on the Dunde ice cap. Proceedings of the Fourth China's National Conference on Glaciology and Geocryology, 37-44. [In Chinese with English abstract.]

Wang Lilun, Liu Chaohai, Kang Xingcheng, and You Genxiang. 1983. Fundamental features of modern glaciers in the Altay Shan of China. J. Glaciol. Cryopedol., 5(4), 27-38. [In Chinese with English abstract.]
Wang Lilun, Zhang Wenjing, and Song Guoping. 1985. Modern glaciers in $\mathrm{mts}$ Tuomuer district. 2.4. The temperature regime in glacier. In Mountaineering Scientific Expedition, Academia Sinica, ed. The glaciology and meteorology in mts Tuomuer district, Tian Shan. Urumqi, Xinjiang People's Publishing House, 64-69. [In Chinese.]

Wang Wenying. 1987. Surveying of glacier variation in the northeastern part of the Qinghai-Xizang Plateau. In Hovermann, J. and Wang Wenying, eds. Reports on the northeastern part of the Qinghai-Xizang (Tibet) Plateau by Sino-W. German Scientific Expedition. Beijing, Science Press, 22-37.

Xie Zhichu and Wang Zongtai. 1975. Ice temperature of Rongbuk glacier. In Comprehensive Scientific Expedition Team to Qinghai-Xizang Plateau, Academia Sinica, ed. Reports of Scientific Expedition to the Region of Mt Qomolangma, 1966-1968 (Glaciology and Geomorphology). Beijing, Science Press, 48-51. [In Chinese.]

Yuan Jianmu, Wang Zhonglong, Deng Yangxing, and Kang Zhicheng. 1982. Basic features of the maritime-type glaciers of the Guxiang region in Xizang Autonomous, China. (Abstract.) In Lanzhou Institute of Glaciology and Geocryology, ed. Proceedings of the Symposium on Glaciology and Cryopedology held by Geographical Society of China (Glaciology). Beijing, Science Press, 21-22. [In Chinese.]

Zhang Jinhua, Ren Jiawen, and Wang Xinzhong. 1984. Ice temperature of Glacier No. 1 at the head of Urumqi River. Annual Report on the Work at Tian Shan Glaciological Station, 2, 124-194. [In Chinese.]

Zhou Tao and Han Jiankan. 1990. Temperature distribution of Chongce ice cap, west Kunlun mts. Kexue Tongbao, 35(3), 212-215. [In Chinese.] 